\title{
Petrography and petrogenesis of some Indian basaltic achondrites derived from the HED parent body: Insights from electron microprobe analyses
}

\author{
RAJESH K SRIVASTAVA \\ Centre of Advanced Study, Department of Geology, Banaras Hindu University, Varanasi 221 005, India. \\ e-mail: rajeshgeolbhu@gmail.com
}

Three Indian achondrites, viz., Bholghati howardite, Lohawat howardite and Pipliya Kalan eucrite and two other achondrites, viz., Béréba eucrite and Johnstown diogenite are studied for their petrography and mineral chemistry. All these achondrites are derived from the HED parent body. Both Bholghati and Lohawat howardites are polymict breccias and contain pieces of eucrites and diaogenites (lithic clasts), pyroxene and minor olivine as mineral clasts, and small proportion of ilmenite and pure iron metal. Eucrite clasts are noncumulate basaltic in nature, whereas diogenite clasts are mostly composed of orthopyroxene with minor clinopyroxene and anorthite. Both howardite samples contain orthopyroxene, pigeonite and augite. Notable characteristics observed in Lohawat howardite include crystallization of orthoenstatite first at a high-temperature followed by ferrosilite, pigeonite olivine and augite from a basaltic melt. Piplia Kalan eucrite is noncumulate, unbrecciated and basaltic in nature and display ophitic/sub-ophitic or hypidiomorphic textures. It contains $\sim 60 \%$ pyroxenes (clinoenstatite and pigeonite) and $\sim 40 \%$ plagioclase feldspars (bytownite to anorthite). The observed mineralogy in the Piplia Kalan eucrite suggests its crystallization from a high-temperature basaltic melt crystallized at low pressure. Two other achondrite samples, viz., Béréba eucrite and Johnstown diogenite are also studied. The Béréba eucrite shows cumulate nature which is probably formed by small-degree melts of ilmenitebearing gabbro, whereas the Johnstown diogenite crystallized from a slow cooling of a Ca-poor basaltic melt derived from cumulates formed from the magma ocean, similar to the origin of the noncumulate eucrites.

\section{Introduction}

Achondrites (differentiated meteorites) are the products of extensive melting accompanied by crystal-liquid fractionation and they show close similarities with the true magmatic rocks in their textures and mineralogy (Mittlefehldt 2005). Therefore, a systematic study of achondrites provides valuable information on the magmatic processes that occurred during the differentiation of small planetary bodies (McSween 1999; Norton 2002; Hutchison 2004). Of the several achondrites known, a group of achondrites that comprise howarditeeucrite-diogenite (HED) meteorites provide us with the largest sampling of magmatic rocks from asteroid 4-Vesta (Drake 2001; Barrat 2004; Barrat et al. 2003, 2010; Mittlefehldt 2005; McSween et al. 2011). This is the most abundant class of achondrites and represents a collection of both volcanic and plutonic rocks formed from basaltic magmas.

Keywords. Indian achondrites; HED clan; petrography; mineral chemistry; petrogenesis. 
The HED suite from the 4-Vesta may provide us valuable knowledge to understand igneous processes happened in a body of known size (Mittlefehldt 2005). A genetic link between the HED clan achondrites is established on the basis of their petrography, mineral chemistry and geochemistry (Duke and Silver 1967; Takeda 1997; Mittlefehldt et al. 1998; McSween 1999; Barrat et al. 2000; Norton 2002; Hutchison 2004 and references therein). In addition, all these diverse meteorites share a common oxygen isotope fractionation line (Clayton and Mayeda 1996; Hutchison 2004) as well as chemical similarities that make them a related suite. The HED suite allows us to associate specific type of igneous processes with a body of known size. The HED suite is composed of mafic and ultramafic igneous rocks, most of which are breccias. This suite comprises three main igneous lithologies - basalt, cumulate gabbro and orthopyroxenite. Eucrites are mostly composed of basaltic/gabbroic compositions. Basaltic eucrites are commonly brecciated in nature and composed of clinopyroxenes (mostly pigeonite) and plagioclase feldspars with minor ilmenite and chromite. They show sub-ophitic/ophtic textures. Cumulate eucrites also have similar mineral compositions but show cumulate texture (Hutchison 2004; Mittlefehldt 2005 and references therein).

In the present communication, some achondrite samples procured from the Physical Research Laboratory (PRL), Ahmedabad, have been studied to understand their mineralogical make-up and petrogenesis. Three Indian achondrites, viz., Bholghati howardite, Lohawat howardite and Pipliya Kalan eucrite are examined for their petrography and mineral chemistry. Bholghati howardite was recovered from Maurbhanj, Orissa in 1905 (Labotka and Papike 1980), Lohawat howardite collected from Lohawat village, Rajasthan in 1994 (Sisodia et al. 2001) and Pipliya Kalan eucrite was recovered from Pipliya Kalan village, Rajasthan in 1996 (Vaya et al. 1996). Two other achondrites, viz., Béréba eucrite and Johnstown diogenite are also studied together with the Indian achondrites for a better understanding.

\section{Material, methodology and results}

Procured samples from PRL were very small in sizes, as small as $0.5 \mathrm{~cm}$, and were either already mounted on a glass slice (Bholghati howardite and Béréba eucrite) or in the form of friable grit (Johnstown diogenite) or as very small pieces (Lohawat howardite and Pipliya Kalan eucrite). It was difficult to prepare a thin section for study under polarized transmitted light microscope; however, a polished mount was prepared for study under reflected light microscope. The given samples were mounted with araldite and left in a PVC mount of 1 inch diameter for a day. After that the grinding and polishing of the sample surface was carried out until mirror polish is obtained. Subsequently various phases were analyzed by electron probe micro analyzer (EPMA) to know their chemical composition. The samples were carbon coated by a Boc Edwards Carbon coating unit and subsequently analyzed by CAMECA SX100 EPMA, dispersive analytical technique using PET, TAP and LLIF crystals at the Indian Bureau of Mines,

Table 1. Representative mineral chemistry (wt.\%) of pyroxenes from Bholghati howardite.

\begin{tabular}{|c|c|c|c|c|c|c|c|c|c|c|c|c|c|c|}
\hline & 1 & 2 & 3 & 4 & 5 & 6 & 7 & 8 & 9 & 10 & 11 & 12 & 13 & 14 \\
\hline $\mathrm{SiO}_{2}$ & 53.10 & 53.16 & 49.13 & 43.42 & 50.08 & 51.17 & 47.62 & 47.58 & 46.02 & 49.09 & 51.49 & 51.69 & 49.37 & 47.16 \\
\hline $\mathrm{TiO}_{2}$ & 0.23 & 0.03 & 0.21 & 0.57 & 0.21 & 0.03 & 0.23 & 0.62 & 0.57 & 0.75 & 0.15 & 0.13 & 0.20 & 0.12 \\
\hline $\mathrm{Al}_{2} \mathrm{O}_{3}$ & 0.28 & 0.32 & 0.28 & 2.41 & 0.21 & 0.57 & 0.14 & 11.99 & 11.99 & 0.69 & 0.21 & 0.43 & 0.58 & 0.58 \\
\hline $\mathrm{FeO}$ & 17.34 & 17.26 & 28.01 & 29.01 & 24.15 & 28.52 & 34.95 & 19.42 & 20.08 & 32.18 & 28.97 & 30.16 & 28.35 & 27.86 \\
\hline $\mathrm{MnO}$ & 0.60 & 0.66 & 0.81 & 1.02 & 0.74 & 0.88 & 1.04 & 0.67 & 0.48 & 0.75 & 0.84 & 1.05 & 0.95 & 0.77 \\
\hline $\mathrm{MgO}$ & 26.44 & 26.46 & 17.94 & 14.37 & 10.95 & 15.27 & 11.98 & 7.66 & 7.66 & 11.76 & 13.53 & 15.49 & 15.32 & 15.48 \\
\hline $\mathrm{CaO}$ & 0.93 & 0.90 & 0.87 & 8.31 & 14.16 & 3.45 & 1.91 & 10.16 & 10.34 & 4.52 & 4.90 & 1.86 & 3.61 & 3.39 \\
\hline $\mathrm{Na}_{2} \mathrm{O}$ & 0.00 & 0.02 & 0.05 & 0.00 & 0.02 & 0.03 & 0.05 & 0.38 & 0.37 & 0.00 & 0.04 & 0.01 & 0.01 & 0.00 \\
\hline $\mathrm{K}_{2} \mathrm{O}$ & 0.00 & 0.03 & 0.01 & 0.03 & 0.01 & 0.00 & 0.00 & 0.10 & 0.00 & 0.00 & 0.00 & 0.01 & 0.00 & 0.02 \\
\hline $\mathrm{Cr}_{2} \mathrm{O}_{3}$ & 0.39 & 0.31 & 0.08 & 0.76 & 0.04 & 0.21 & 0.22 & 0.29 & 0.30 & 0.49 & 0.21 & 0.12 & 0.09 & 0.19 \\
\hline Total & 99.31 & 99.15 & 97.39 & 99.90 & 100.57 & 100.13 & 98.14 & 98.87 & 97.81 & 100.23 & 100.34 & 100.95 & 98.48 & 95.57 \\
\hline Wo & 1.80 & 1.74 & 1.78 & 16.33 & 29.06 & 7.23 & 4.10 & 27.06 & 27.21 & 9.71 & 10.39 & 3.89 & 7.57 & 7.21 \\
\hline En & 71.25 & 71.29 & 50.94 & 39.29 & 31.27 & 44.54 & 35.81 & 28.39 & 28.05 & 35.14 & 39.93 & 45.05 & 44.69 & 45.80 \\
\hline $\mathrm{Fs}$ & 26.95 & 26.90 & 45.24 & 44.39 & 39.60 & 48.12 & 59.89 & 42.72 & 42.97 & 55.16 & 49.53 & 51.02 & 47.70 & 46.99 \\
\hline Px Class & Fe-P En & Fe-P En & Fe-R En & FeSill & $\mathrm{Ag}$ & $\mathrm{Pg}$ & FeSill & $\mathrm{Ag}$ & $\mathrm{Ag}$ & $\mathrm{Pg}$ & $\mathrm{Pg}$ & $\mathrm{Pg}$ & $\mathrm{Pg}$ & $\mathrm{Pg}$ \\
\hline
\end{tabular}

Fe-P En: Iron-poor enstatite; Fe-R En: Iron-rich enstatite; FeSill: Ferrosilite; Ag: Augite; Pg: Pigeonite. 
Table 2. Representative mineral chemistry (wt.\%) of pyroxenes from Lohawat howardite.

\begin{tabular}{|c|c|c|c|c|c|c|c|c|c|c|c|c|c|c|c|}
\hline & 1 & 2 & 3 & 4 & 5 & 6 & 7 & 8 & 9 & 10 & 11 & 12 & 13 & 14 & 15 \\
\hline $\mathrm{SiO}_{2}$ & 51.83 & 52.79 & 47.37 & 53.07 & 50.64 & 57.70 & 51.57 & 49.08 & 47.35 & 47.72 & 50.58 & 53.87 & 47.13 & 48.22 & 48.79 \\
\hline $\mathrm{TiO}_{2}$ & 0.17 & 0.11 & 0.15 & 0.19 & 0.46 & 0.08 & 0.85 & 0.62 & 0.35 & 0.33 & 0.29 & 0.23 & 0.27 & 0.28 & 0.34 \\
\hline $\mathrm{Al}_{2} \mathrm{O}_{3}$ & 0.72 & 0.69 & 0.49 & 0.79 & 1.42 & 0.89 & 1.91 & 1.05 & 0.35 & 7.32 & 3.00 & 0.83 & 0.24 & 0.21 & 0.59 \\
\hline $\mathrm{FeO}$ & 28.48 & 27.29 & 34.31 & 14.72 & 26.94 & 13.20 & 11.49 & 17.08 & 30.39 & 19.59 & 22.75 & 14.54 & 35.77 & 35.57 & 16.50 \\
\hline $\mathrm{MnO}$ & 0.74 & 0.82 & 1.07 & 0.54 & 0.81 & 0.47 & 0.42 & 0.54 & 0.93 & 0.57 & 0.70 & 0.49 & 0.96 & 1.09 & 0.53 \\
\hline $\mathrm{MgO}$ & 17.02 & 18.89 & 10.52 & 27.02 & 13.98 & 29.26 & 12.72 & 15.47 & 15.80 & 15.10 & 16.62 & 25.12 & 12.06 & 12.88 & 11.16 \\
\hline $\mathrm{CaO}$ & 1.40 & 1.11 & 5.53 & 1.61 & 6.62 & 1.10 & 21.83 & 13.85 & 2.33 & 7.20 & 4.76 & 1.42 & 3.52 & 1.95 & 20.07 \\
\hline $\mathrm{Na}_{2} \mathrm{O}$ & 0.02 & 0.00 & 0.06 & 0.06 & 0.05 & 0.01 & 0.17 & 0.17 & 0.03 & 0.12 & 0.05 & 0.05 & 0.07 & 0.04 & 0.09 \\
\hline $\mathrm{K}_{2} \mathrm{O}$ & 0.03 & 0.05 & 0.00 & 0.05 & 0.01 & 0.00 & 0.01 & 0.00 & 0.01 & 0.22 & 0.03 & 0.02 & 0.04 & 0.05 & 0.00 \\
\hline $\mathrm{Cr}_{2} \mathrm{O}_{3}$ & 0.37 & 0.17 & 0.51 & 0.64 & 0.99 & 0.69 & 0.56 & 0.42 & 1.04 & 0.75 & 0.77 & 0.63 & 0.16 & 0.17 & 0.24 \\
\hline Total & 100.78 & 101.92 & 100.01 & 98.69 & 101.92 & 103.40 & 101.53 & 98.28 & 98.58 & 98.92 & 99.55 & 97.20 & 100.22 & 100.46 & 98.31 \\
\hline Wo & 2.92 & 2.25 & 11.63 & 3.15 & 13.85 & 2.09 & 44.45 & 28.10 & 4.81 & 16.30 & 10.27 & 2.94 & 7.24 & 4.16 & 41.04 \\
\hline En & 49.37 & 53.28 & 30.79 & 73.48 & 40.69 & 77.48 & 36.04 & 43.68 & 45.38 & 47.58 & 49.90 & 72.40 & 34.53 & 38.28 & 31.75 \\
\hline Fs & 47.63 & 44.47 & 57.35 & 23.16 & 45.27 & 20.40 & 18.89 & 27.59 & 49.70 & 35.63 & 39.63 & 24.47 & 57.96 & 57.40 & 26.87 \\
\hline Px Class & FeSill & Fe-R En & $\mathrm{Pg}$ & Fe-P En & $\mathrm{Pg}$ & Fe-P En & $\mathrm{Ag}$ & $\mathrm{Ag}$ & FeSill & $\mathrm{Pg}$ & $\mathrm{Pg}$ & Fe-P En & $\mathrm{Pg}$ & FeSill & $\mathrm{Ag}$ \\
\hline
\end{tabular}

Fe-P En: Iron-poor enstatite; Fe-R En: Iron-rich enstatite; FeSill: Ferrosilite; Ag: Augite; Pg: Pigeonite.

Table 3. Representative mineral chemistry (wt.\%) of plagioclase feldspars from studied HED clan achondrite samples.

\begin{tabular}{|c|c|c|c|c|c|c|c|c|c|c|c|c|c|c|}
\hline & \multicolumn{2}{|c|}{$\begin{array}{l}\text { Bholghati } \\
\text { howardite }\end{array}$} & \multirow{2}{*}{$\begin{array}{l}\begin{array}{c}\text { Johnstown } \\
\text { diogenite }\end{array} \\
1\end{array}$} & \multicolumn{3}{|c|}{ Lohawat howardite } & \multicolumn{8}{|c|}{ Pipliya Kalan eucrite } \\
\hline & 1 & 2 & & 1 & 2 & 3 & 1 & 2 & 3 & 4 & 5 & 6 & 7 & 8 \\
\hline $\mathrm{SiO}_{2}$ & 45.11 & 47.72 & 44.41 & 50.58 & 50.52 & 49.65 & 47.54 & 46.42 & 42.41 & 47.63 & 48.58 & 53.42 & 49.08 & 44.12 \\
\hline $\mathrm{TiO}_{2}$ & 0.03 & 0.00 & 0.00 & 0.00 & 0.10 & 0.00 & 0.00 & 0.01 & 0.03 & 0.00 & 0.00 & 0.01 & 0.00 & 0.00 \\
\hline $\mathrm{Al}_{2} \mathrm{O}_{3}$ & 29.85 & 32.25 & 31.03 & 33.02 & 30.11 & 33.12 & 32.22 & 32.31 & 34.23 & 33.55 & 34.18 & 28.22 & 25.98 & 30.07 \\
\hline $\mathrm{FeO}$ & 3.31 & 0.69 & 0.10 & 0.05 & 1.52 & 0.22 & 0.07 & 0.40 & 0.16 & 0.04 & 0.02 & 0.00 & 0.18 & 0.94 \\
\hline $\mathrm{MnO}$ & 0.07 & 0.00 & 0.04 & 0.00 & 0.03 & 0.00 & 0.00 & 0.04 & 0.01 & 0.00 & 0.01 & 0.00 & 0.00 & 0.04 \\
\hline $\mathrm{MgO}$ & 1.03 & 0.05 & 0.02 & 0.06 & 0.44 & 0.14 & 0.18 & 0.93 & 0.16 & 0.04 & 0.02 & 0.18 & 0.43 & 1.79 \\
\hline $\mathrm{CaO}$ & 18.63 & 17.40 & 16.66 & 17.32 & 17.23 & 18.32 & 18.54 & 18.29 & 18.14 & 18.18 & 18.27 & 15.99 & 18.14 & 16.44 \\
\hline $\mathrm{Na}_{2} \mathrm{O}$ & 0.41 & 1.37 & 1.65 & 1.79 & 1.88 & 1.52 & 1.02 & 1.19 & 1.14 & 1.67 & 1.32 & 1.21 & 1.34 & 0.95 \\
\hline $\mathrm{K}_{2} \mathrm{O}$ & 0.03 & 0.13 & 0.12 & 0.00 & 0.02 & 0.15 & 0.04 & 0.11 & 0.03 & 0.09 & 0.05 & 0.07 & 0.08 & 0.07 \\
\hline $\mathrm{Cr}_{2} \mathrm{O}_{3}$ & 0.10 & 0.04 & 0.00 & 0.03 & 0.00 & 0.00 & 0.00 & 0.01 & 0.03 & 0.00 & 0.00 & 0.02 & 0.02 & 0.00 \\
\hline Total & 98.57 & 99.65 & 94.03 & 102.85 & 101.85 & 103.12 & 99.61 & 99.71 & 96.34 & 101.20 & 102.45 & 99.12 & 95.25 & 94.42 \\
\hline An & 95.99 & 86.85 & 91.20 & 83.71 & 83.49 & 86.21 & 90.73 & 88.90 & 89.63 & 85.32 & 88.18 & 87.55 & 87.80 & 90.12 \\
\hline $\mathrm{Ab}$ & 3.82 & 12.37 & 8.56 & 15.66 & 16.40 & 12.94 & 9.03 & 10.47 & 10.19 & 14.18 & 11.53 & 11.99 & 11.74 & 9.42 \\
\hline Or & 0.18 & 0.77 & 0.25 & 0.63 & 0.11 & 0.84 & 0.23 & 0.64 & 0.18 & 0.50 & 0.29 & 0.46 & 0.46 & 0.46 \\
\hline
\end{tabular}

Nagpur. PEAKSIGHT online software program developed by CAMECA was used to acquire and process the data. The generated data was corrected by using an on-line PAP-correction program. During the study, back scattered electron (BSE) imaging was also performed at very high magnifications to differentiate between various phases a beam diameter of $1 \mu$, an acceleration voltage of $15 \mathrm{kV}$, a beam current of $12 \mathrm{nA}$ and counting time of up to $20 \mathrm{~s}$ were used. After repeated analyses of standards along with the minerals of interest it was observed that error on the elements was less than $1 \%$. The EPMA data is presented in tables $1-5$ and (BSE) images are presented in figures $1-5$.

\section{Petrography and mineral chemistry}

\subsection{Bholghati howardite}

Polished section of Bholghati howardite clearly shows a brecciated texture. It is a polymict breccia which contains lithic clasts (pieces of eucrites 
Table 4. Representative mineral chemistry (wt.\%) of olivine, chromite and ilmenite from studied HED clan achondrite samples.

\begin{tabular}{|c|c|c|c|c|c|c|c|c|c|c|}
\hline & \multicolumn{4}{|c|}{ Lohawat howardite } & \multicolumn{2}{|c|}{ Bholghati howardite } & \multirow{2}{*}{$\frac{\text { Béréba eucrite }}{\mathrm{Cr}}$} & \multicolumn{3}{|c|}{ Johnstown diogenite } \\
\hline & $\mathrm{Ol}$ & $\mathrm{Ol}$ & $\mathrm{Cr}$ & Il & $\mathrm{Cr}$ & $\mathrm{Il}$ & & Il & Il & Il \\
\hline $\mathrm{SiO}_{2}$ & 29.27 & 30.98 & 0.00 & 0.00 & 0.00 & 0.00 & 0.01 & 0.83 & 0.00 & 0.00 \\
\hline $\mathrm{TiO}_{2}$ & 0.04 & 0.10 & 7.72 & 54.87 & 0.81 & 53.22 & 0.06 & 52.69 & 49.75 & 49.79 \\
\hline $\mathrm{Al}_{2} \mathrm{O}_{3}$ & 0.01 & 0.01 & 8.34 & 0.00 & 9.56 & 0.00 & 8.99 & 0.00 & 0.02 & 0.00 \\
\hline $\mathrm{FeO}$ & 65.61 & 64.33 & 36.47 & 46.60 & 23.12 & 44.31 & 28.91 & 43.16 & 42.13 & 42.55 \\
\hline $\mathrm{MnO}$ & 1.57 & 1.56 & 0.51 & 0.92 & 0.38 & 0.82 & 0.53 & 0.97 & 0.75 & 0.84 \\
\hline $\mathrm{MgO}$ & 4.83 & 4.04 & 4.70 & 0.33 & 5.95 & 0.92 & 2.55 & 0.62 & 0.63 & 0.59 \\
\hline $\mathrm{CaO}$ & 0.06 & 0.15 & 0.14 & 0.01 & 0.08 & 0.03 & 0.03 & 0.00 & 0.04 & 0.02 \\
\hline $\mathrm{Na}_{2} \mathrm{O}$ & 0.00 & 0.07 & 0.34 & 0.05 & 0.01 & 0.03 & 0.02 & 0.00 & 0.00 & 0.02 \\
\hline $\mathrm{K}_{2} \mathrm{O}$ & 0.00 & 0.00 & 0.12 & 0.01 & 0.00 & 0.03 & 0.00 & 0.00 & 0.00 & 0.00 \\
\hline $\mathrm{Cr}_{2} \mathrm{O}_{3}$ & 0.03 & 0.01 & 43.03 & 0.00 & 58.43 & 0.14 & 58.21 & 0.15 & 0.11 & 0.01 \\
\hline Total & 101.42 & 101.25 & 101.37 & 102.79 & 98.34 & 99.50 & 99.31 & 98.42 & 93.43 & 93.82 \\
\hline Fo & 11.36 & 9.85 & & & & & & & & \\
\hline $\mathrm{Fa}$ & 86.54 & 87.99 & & & & & & & & \\
\hline
\end{tabular}

Ol: Olivine; Cr: Chromite; Il: Ilmenite.

Table 5. Representative mineral chemistry (wt.\%) of pyroxenes from Béréba eucrite and Johnstown diogenite.

\begin{tabular}{|c|c|c|c|c|c|c|c|}
\hline & \multicolumn{5}{|c|}{ Béréba eucrite } & \multicolumn{2}{|c|}{ Johnstown diogenite } \\
\hline & 1 & 2 & 3 & 4 & 5 & 1 & 2 \\
\hline $\mathrm{SiO}_{2}$ & 52.09 & 56.05 & 52.10 & 53.56 & 53.00 & 44.89 & 49.89 \\
\hline $\mathrm{TiO}_{2}$ & 0.23 & 0.15 & 0.19 & 0.12 & 0.05 & 0.03 & 0.54 \\
\hline $\mathrm{Al}_{2} \mathrm{O}_{3}$ & 1.11 & 1.09 & 1.13 & 1.13 & 1.08 & 0.12 & 0.16 \\
\hline $\mathrm{FeO}$ & 15.25 & 15.31 & 15.66 & 15.94 & 15.16 & 32.50 & 32.35 \\
\hline $\mathrm{MnO}$ & 0.44 & 0.47 & 0.44 & 0.54 & 0.52 & 1.09 & 1.13 \\
\hline $\mathrm{MgO}$ & 27.27 & 26.71 & 26.77 & 27.40 & 26.87 & 11.97 & 12.61 \\
\hline $\mathrm{CaO}$ & 1.50 & 1.65 & 1.62 & 1.45 & 1.54 & 1.93 & 1.13 \\
\hline $\mathrm{Na}_{2} \mathrm{O}$ & 0.00 & 0.00 & 0.00 & 0.01 & 0.01 & 0.03 & 0.03 \\
\hline $\mathrm{K}_{2} \mathrm{O}$ & 0.00 & 0.01 & 0.00 & 0.00 & 0.00 & 0.00 & 0.00 \\
\hline $\mathrm{Cr}_{2} \mathrm{O}_{3}$ & 0.90 & 0.81 & 0.88 & 0.87 & 0.80 & 0.05 & 0.11 \\
\hline Total & 98.79 & 102.25 & 98.79 & 101.02 & 99.03 & 92.61 & 97.95 \\
\hline Wo & 2.91 & 3.22 & 3.16 & 2.77 & 2.97 & 4.33 & 2.51 \\
\hline En & 73.56 & 72.61 & 72.57 & 72.81 & 73.16 & 37.37 & 38.94 \\
\hline Fs & 23.53 & 24.16 & 24.28 & 24.39 & 23.83 & 58.18 & 58.43 \\
\hline Px Class & \multicolumn{5}{|c|}{ Iron-poor enstatite } & \multicolumn{2}{|c|}{ Ferrosilite } \\
\hline
\end{tabular}

and diaogenites), mineral clasts (mostly different varieties of pyroxenes and miner ilmenite), and small amount of pure iron metallic phase (Fe total is $98.87 \mathrm{wt} \%)$. Eucrite clasts clearly show ophitic texture; big pigeonite grains enclose plagioclase feldspar laths (figure 1c, e). The EPMA data on pyroxenes of Bholghati howardite is presented in table 1 . These pigeonites are rich in iron $\left(\mathrm{En}_{39.93-35.14} \mathrm{Fs}_{55.16-49.53} \mathrm{Wo}_{10.39-9.71}\right)$, whereas enclosed plagioclase feldspar composition is similar to bytownite $\left(\mathrm{An}_{86.85}\right.$; table 3$)$. Lithic diogenitic clasts are also observed which contain orthopyroxene (in form of ferrosilite: $\mathrm{En}_{35.81} \mathrm{Fs}_{59.89} \mathrm{WO}_{4.10}$ ), clinopyroxene (as pigeonite: $\mathrm{En}_{44.54} \mathrm{Fs}_{48.12} \mathrm{WO}_{7.23}$ ), anorthite $\left(\mathrm{An}_{95.99}\right.$; table 3$)$ and ilmenite (figure $\left.1 \mathrm{~b}\right)$. Mineral clasts, mostly anhedral angularsubangular to subhedral in shape, present in this sample include orthopyroxene (Fe-poor enstatite: $\mathrm{Fn}_{71.29-71.25} \mathrm{FS}_{26.95-26.90} \mathrm{Wo}_{1.80-1.74}$; Fe-rich enstatite: $\mathrm{En}_{50.94} \mathrm{Fs}_{45.24} \mathrm{Wo}_{1.78}$ and ferrosilite: $\mathrm{En}_{39.29} \mathrm{Fs}_{44.39}$ $\mathrm{Wo}_{16.39}$ ), clinopyroxene (pigeonite: $\mathrm{En}_{45.80-44.69}$ $\mathrm{Fs}_{51.02-46.99} \mathrm{Wo}_{7.57-3.89}$ and augite: $\mathrm{En}_{28.39-28.05}$ 

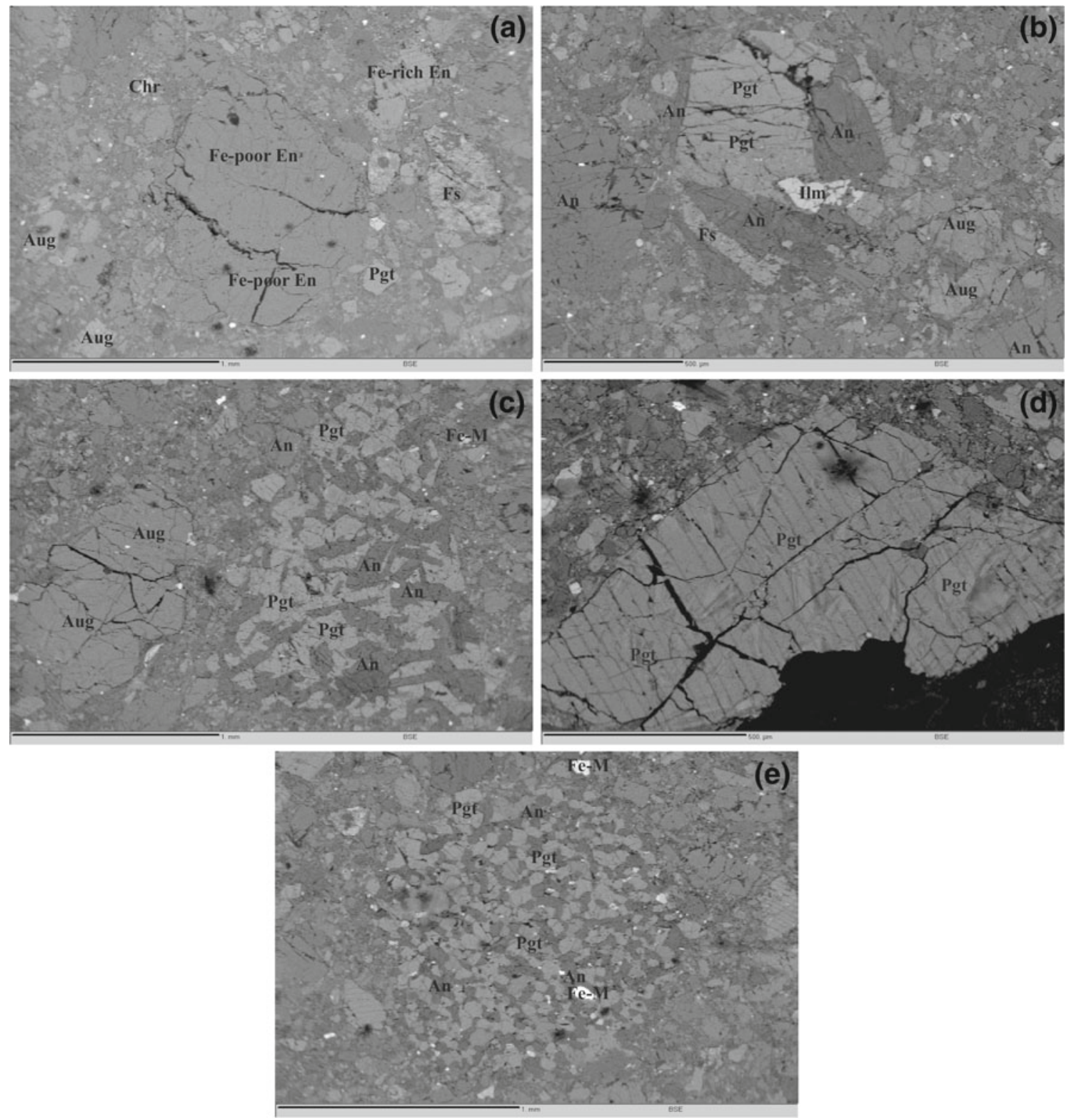

Figure 1. (a-e) Back Scattered Electron (BSE) images of Bholghati howardite. En: enstatite; Fs: ferrosilite; Pgt: pigeonite; Aug: Augite; An: anorthite-bytwonite; Ilm: Ilmenite; Fe-M: pure iron metal.

$\mathrm{Fs}_{42.97-42.72} \mathrm{Wo}_{27.21-27.06}$ ) (see figure 1a, c, d). Pure iron metal is also present (figure 1c, e). These lithic and mineral clasts are set in a matrix of fineto medium-grained mineral fragments.

\subsection{Lohabat howardite}

Similar to Bholghati howardite, Lohawat howardite also shows brecciated texture due to presence of polymict breccias (figure 2). Eucrite (figure 2a, e) and diaogenite (figure 2d) lithic clasts, many mineral clasts (mostly orthopyroxene and a few grains of chromite and ilmenite) and pure iron metallic phase (Fe total is $\sim 99 \mathrm{wt} \%$ ) are very clearly visible in the polished section. The EPMA data on pyroxenes of Lohabat howardite is presented in table 1. Figure 2(a) shows lithic eucrite clast showing ophitic texture; a big orthopyroxene (Ferich ferrosilite: $\mathrm{En}_{49.37} \mathrm{Fs}_{47.63} \mathrm{WO}_{2.92}$ ) grain encloses several grains of plagioclase feldspar (bytownite; $\mathrm{An}_{83.71}$; table 3 ). Another ophitic textured lithic eucrite clast may be seen in figure 2(e), in which a big clinopyroxene (pigeonite: $\operatorname{En}_{49.90}$ $\left.\mathrm{Fs}_{39.63} \mathrm{Wo}_{10.27}\right)$ encloses laths of bytownite $\left(\mathrm{An}_{86.21-83.49}\right.$; table 3$)$. A number of lithic diogenite clasts are present in the studied Lohawat 

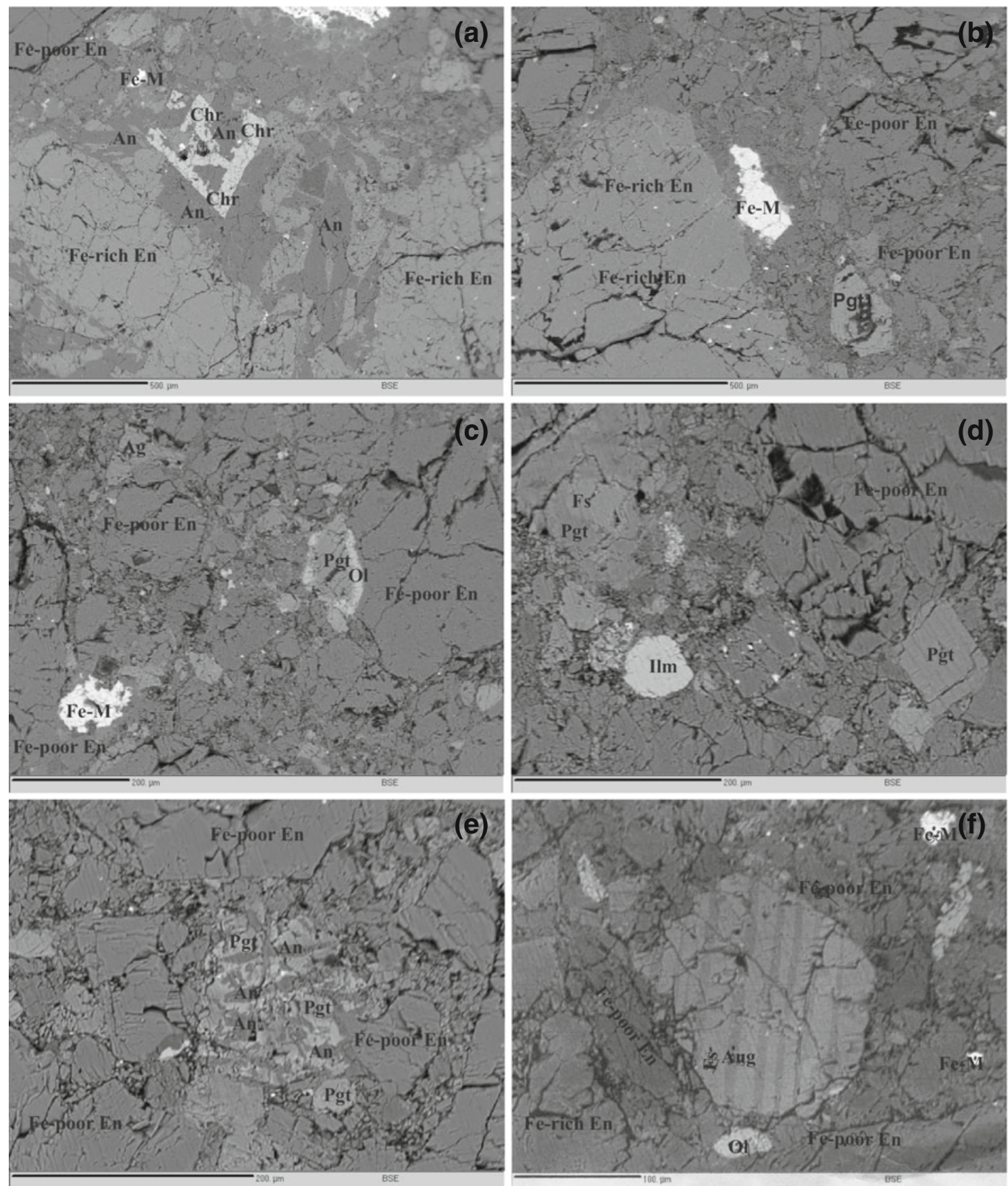

Figure 2. (a-f) Back scattered electron (BSE) images of Lohawat howardite. En: enstatite; Fs: ferrosilite; Pgt: pigeonite; Aug: augite; Ol: olivine; An: anorthite-bytwonite; Ilm: ilmenite; Chr: chromite; Fe-M: pure iron metal.

howardite sample (figure 2c, d). Diogenite clast visible in figure 2(c) is composed of orthopyroxene (Fe-poor enstatite: $\mathrm{En}_{77.48} \mathrm{Fs}_{20.40} \mathrm{WO}_{2.09}$ ), clinopyroxene (pigeonite: $\mathrm{En}_{40.69} \mathrm{Fs}_{45.27} \mathrm{Wo}_{13.85}$ ) and fayalite olivine $\left(\mathrm{Fo}_{11.36} \mathrm{Fa}_{86.54}\right.$; table 4$)$. This pigeonite and olivine display a beautiful corona texture; core pigeonite surrounded by rim olivine. Another diogenite clast (figure 2d) is mainly composed of orthopyroxenes (Fe-poor enstatite). In the same BSE image a diogenite clast consists of orthopyroxe (ferrosilite: $\mathrm{En}_{45.38} \mathrm{Fs}_{49.70} \mathrm{WO}_{4.81}$ ) and clinopyroxene (pigeonite: $\mathrm{En}_{47.58} \mathrm{Fs}_{35.63} \mathrm{Wo}_{16.30}$ ). This clast clearly shows crystallization of pigeonite from ferrosilite. Numerous euhedral to subhedral mineral clasts are observed. Amongst orthopyroxenes, Fepoor enstatite $\left(\mathrm{En}_{73.48-72.40} \mathrm{Fs}_{24.47-23.16} \mathrm{Wo}_{3.15-2.94}\right)$ and Fe-rich enstatite $\left(\mathrm{En}_{53.28} \mathrm{Fs}_{44.47} \mathrm{WO}_{2.25}\right)$ and amongst clinopyroxenes, pigeonite $\left(\mathrm{En}_{34.53-30.79}\right.$ $\left.\mathrm{Fs}_{57.96-57.35} \mathrm{Wo}_{11.63-7.24}\right)$ and augite $\left(\mathrm{En}_{43.68-36.04}\right.$ $\left.\mathrm{Fs}_{27.59-18.89} \mathrm{Wo}_{44.45-28.10}\right)$ are present in the 

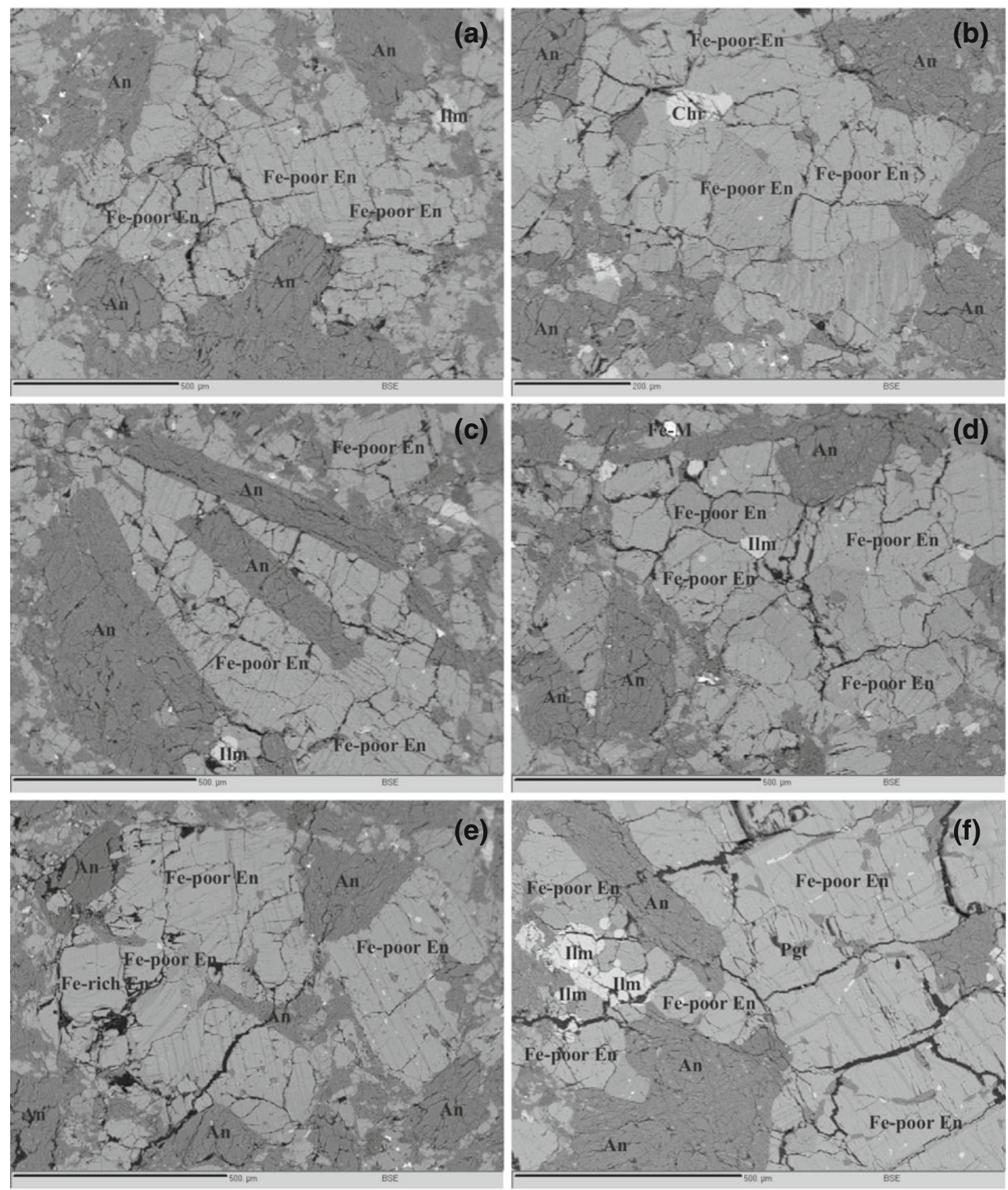

Figure 3. (a-f) Back scattered electron (BSE) images of Pipliya Kalan eucrite. En: enstatite; Pgt: pigeonite; An: anorthitebytwonite; Ilm: ilmenite; Fe-M: pure iron metal.

howardite sample. Other minor phases include an anchor-shaped chromite grain (figure 2a), grains of pure iron metal (figure $2 \mathrm{~b}, \mathrm{c}, \mathrm{f}$ ), and ilmenite (figure 2d). Small olivine grains of fayalitic composition $\left(\mathrm{Fo}_{9.85} \mathrm{Fa}_{87.99}\right)$ are also present (figure 2c, $\mathrm{f}$ ). The recorded lithic and mineral clasts are set in a matrix of fine- to medium-grained mineral fragments. In figure 2(f), the augite $\left(\mathrm{En}_{31.75} \mathrm{Fs}_{26.87} \mathrm{Wo}_{41.87}\right)$ is seen to be exsolving at the expanse of ferrosilite $\left(\mathrm{En}_{38.28} \mathrm{Fs}_{57.40} \mathrm{WO}_{4.16}\right)$; which is a characteristic feature of cumulate type eucrites (Takeda 1997).

\subsection{Pipliya Kalan eucrite}

Polished section of Pipliya Kalan eucrite shows hypidiomorphic (figure 3b, d, e) to ophitic/subophitic textures (figure $3 \mathrm{a}, \mathrm{c}, \mathrm{f}$ ). Hypidiomorphic texture is constituted of holocrystalline subhedral pyroxene and plagioclase feldspar grains. Ophitic/sub-ophitic textures are defined by the presence of subhedral laths of plagioclase feldspars embedded in pyroxene grains (figure 3). Chromite $(\mathrm{Chr})$, ilmenite (Ilm) and iron-metal (Fe-M) are 

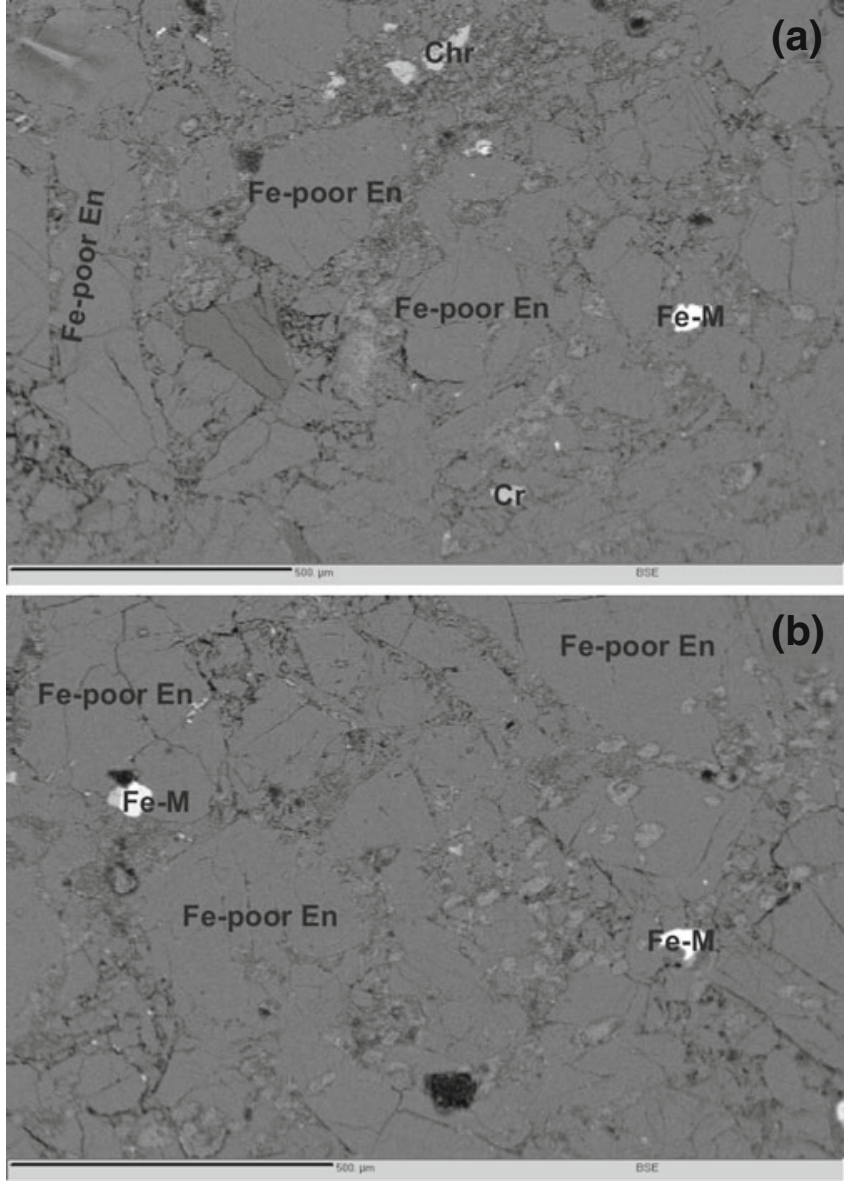

Figure 4. (a and b) Back scattered electron (BSE) images of Béréba eucrite. En: enstatite; Chr: chromite; Fe-M: pure iron metal.

present as minor phases. Modally, this sample contains $\sim 60 \%$ pyroxenes and $\sim 40 \%$ plagioclase feldspars. During the examination of polished section it is observed that most of the pyroxene grains are altered and it is difficult to get any fresh grain. Because of this reason it was difficult to get good EPMA data for the pyroxene grains and hence low total. Therefore, EPMA data of pyroxenes from this sample are not presented; however these data indicate presence of Fe-poor clinoenstatite. Few small grains of pigeonite are also visible at places (figure 3f). A small number of pyroxene grains also show Fe-rich enstatite composition but ferrosilite is not noticed. Plagioclase feldspars are fresh and many grains are analyzed for their chemical makeup (table 3). Most feldspar grains show their composition similar to bytownite $\left(\mathrm{An}_{85.32-88.90}\right)$. A couple of feldspar grains show anorthite composition $\left(\mathrm{An}_{90.12-90.73}\right)$ (see figure 7 ).

\subsection{Béréba eucrite}

Polished section of Béréba eucrite exhibits brecciated to cumulate textures, however, brecciated
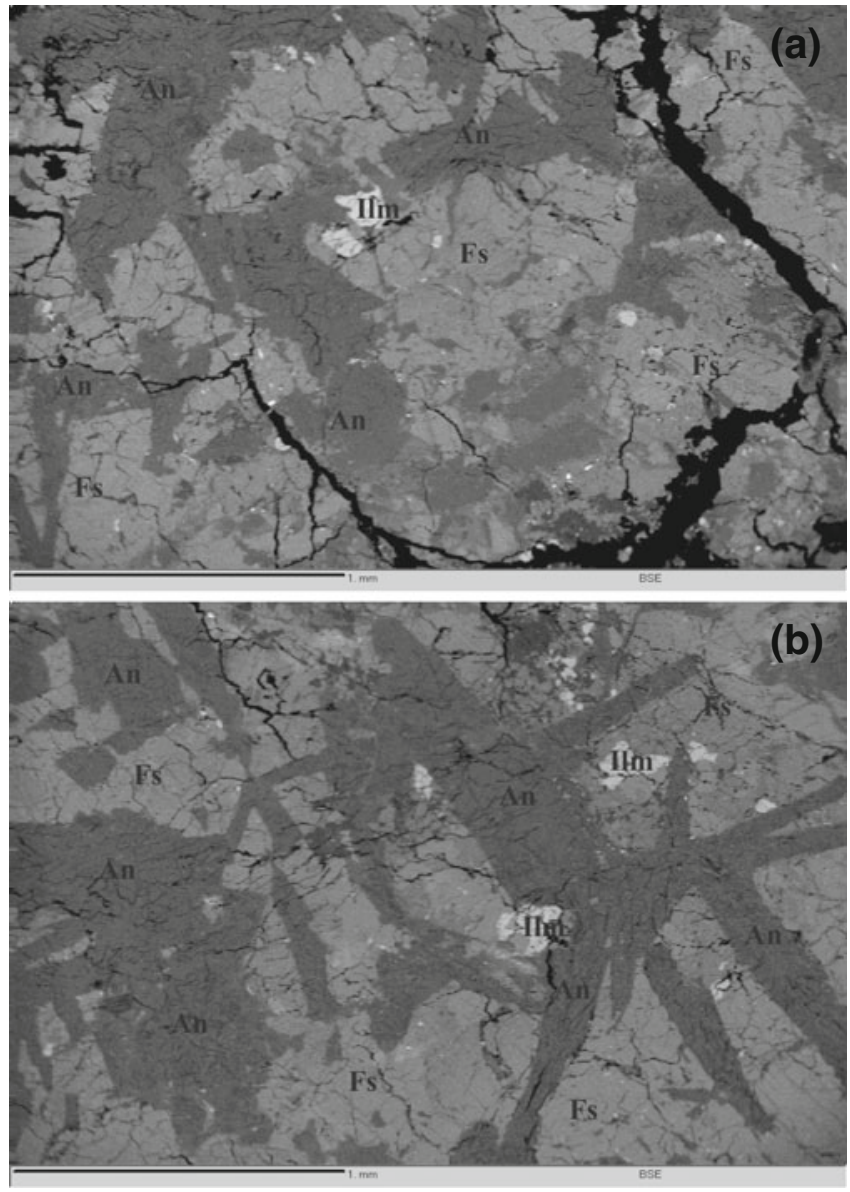

Figure 5. (a and b) Back scattered electron (BSE) images of Johnstown diogenite. Fs: ferrosilite; An: anorthitebytwonite; Ilm: ilmenite; Fe-M: pure iron metal.

texture is more prominent. Most part of the sample consists of anhedral pyroxene grains embedded in a fine-grained groundmass (figure 4). Rarely plagioclase is noticed; but presence of very small grains of plagioclase feldspar in groundmass cannot be ruled out. This lead to its identification as brecciated cumulate texture as pyroxenes are very likely a part of a cumulate crystallized from a basaltic melt. The modal abundances of pyroxene is more than $85 \%$, rest forms fine-grained groundmass and minor phases. Noticed minor phases are chromite and iron-metal (Fe total is $\sim 99 \mathrm{wt} \%$ ). This feature indicates its cumulate nature. Therefore, studied sample of Béréba eucrite may be classified as a cumulate monomict eucrite (cf. Takeda 1997; Hutchison 2004). These pyroxene grains are analyzed by EPMA (see table 5) which reveal their high-Mg, low-Fe and low-Ca nature, and therefore they can be classified as clinoenstatite $\left(\mathrm{En}_{73.56-72.57} \mathrm{Fs}_{24.39-23.53} \mathrm{Wo}_{3.22-2.77}\right.$; Fe-poor enstatite; see figure 6). 


\subsection{Johnstown diogenite}

Polished section of Johnstown diogenite exhibits hypidiomorphic to ophitic textures (figure 5). At places brecciated nature is also observed. Ophitic texture is displayed by rains of plagioclase feldspar enclosed by pyroxene grains. Most minerals, either pyroxene or plagioclase feldspar, are subhedral in

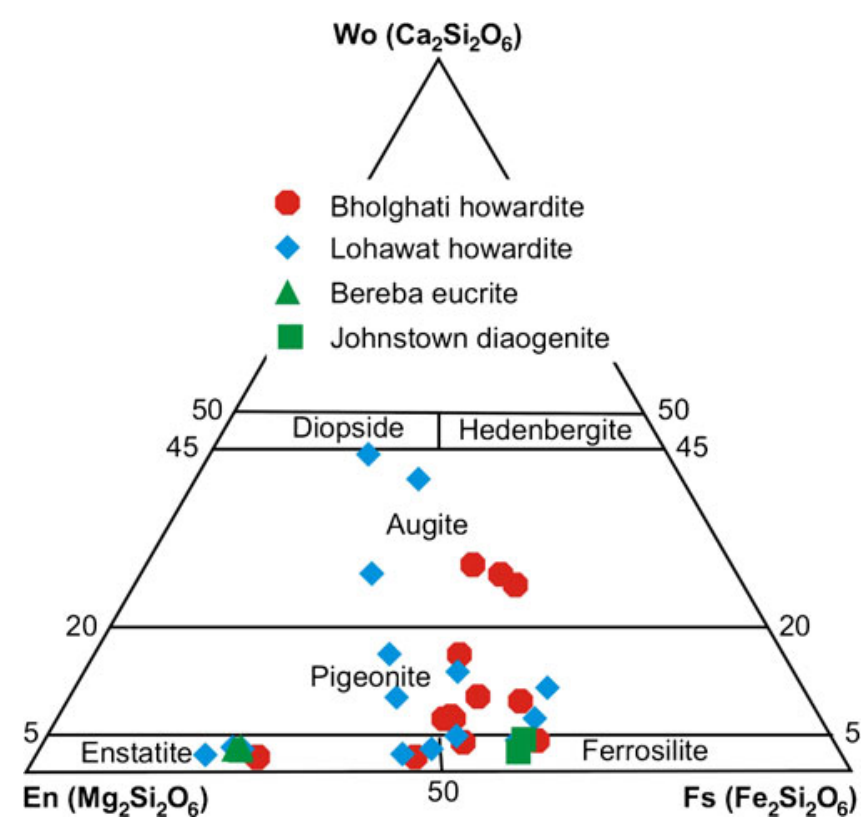

Figure 6. Pyroxene classification based on En-Wo-Fs compositions (after Morimoto et al. 1988).

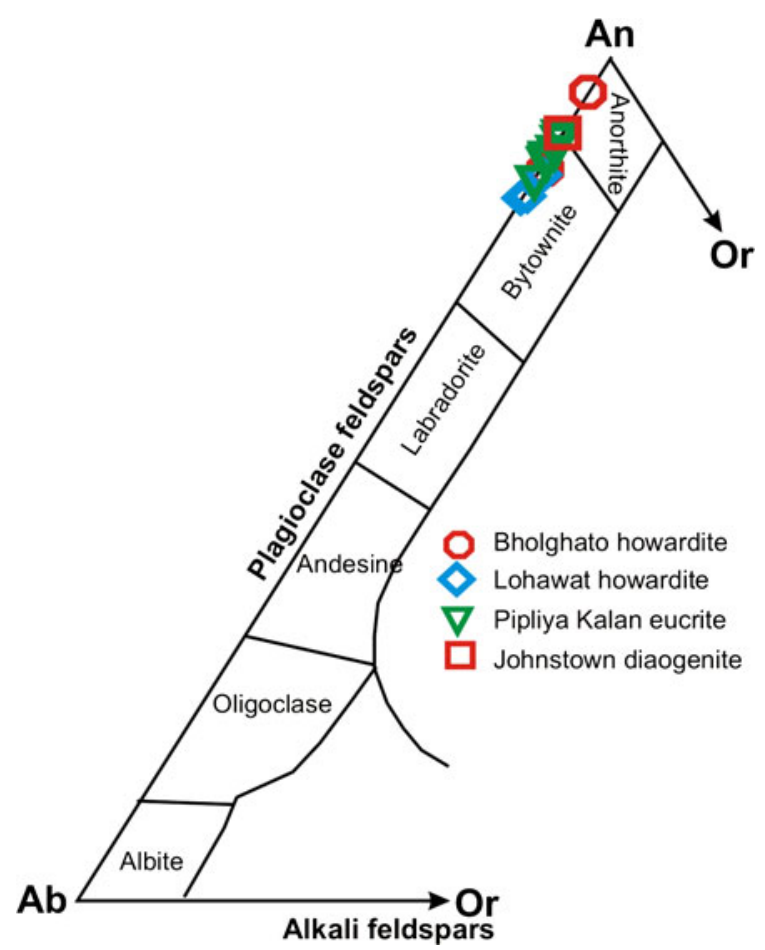

Figure 7. Feldspar compositions of the studied HED clan samples. shape. Minor phases present in this sample is either ilmenite (Ilm) or iron-metal (Fe-M). Similar to Pipliya Kalan eucrite, most pyroxene grains are altered and, therefore, it was difficult to get good EPMA data. A couple of grains gave good results which suggest presence of iron-rich orthopyroxenes i.e., ferrosilites $\left(\mathrm{En}_{38.94-37.37} \mathrm{Fs}_{58.43-58.18} \mathrm{Wo}_{4.33-2.51}\right)$ in this achondrite (table 5 and figure 6 ). Plagioclase feldspars are also altered; one fresh grain from this sample was analysed which suggests it to be an anorthite $\left(\mathrm{An}_{91.20}\right.$; table 3$)$ (figure 7$)$. Modally $\sim 70 \%$ of the sample is made up of pyroxene grains and rest is plagioclase feldspar.

\section{Discussion}

\subsection{Bholghati and Lohawat howardites}

Petrographic properties and mineral chemistry of the studied achondrite samples of HED clan clearly indicate their asteroidal nature. As observed in most of the known howardite samples, both the studied samples (Bholghati and Lohawat howardites) are polymict breccias and show brecciated texture. Lithic and mineral clasts present in the studied howardite samples are set in a matrix of fine- to medium-grained mineral fragments. Low Fo olivine is known from the howardites (Delaney et al. 1980). Pyroxene composition observed in both the studied howardites is very similar; both contain orthopyroxenes (Fe-poor enstatite, Fe-rich enstatite and ferrosilite), pigeonite and augite (see figure 8). Pyroxenes from lithic and mineral clasts

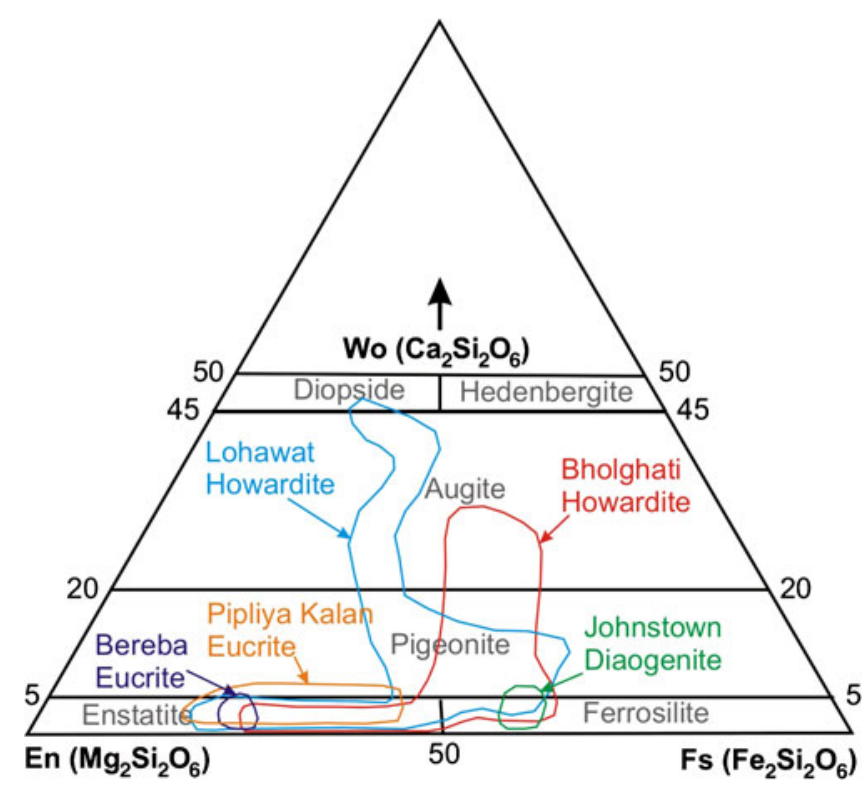

Figure 8. Composition range of pyroxenes of the studied achondrites for comparison. 
of different diogenites, viz., Yurtuk, Frankfort, ALHA 77302, ALHA 78006, Pavlovka, Malvern and Bununu also show similar chemical compositions (Labotka and Papike 1980). It is established that pyroxenes crystallized at low pressure from a basaltic magma consisting of orthopyroxene, pigeonite and augite demonstrate a wide solvus at magmatic temperatures, i.e., large range in temperatures of crystallization (Huebner 1980). Additionally, Lohawat howardite shows some remarkable attributes, which includes a corona texture exhibited by pigeonite (core) and olivine (rim), crystallization of pigeonite from ferrosilite and fine exsolution lamellae of augite within ferrosilite. These features explain crystallization sequence of pyroxene. High-Mg orthopyroxenes (enstatite) crystallize first at a high-temperature followed by ferrosilite, pigeonite olivine and augite (cf. Biggar 1985). Corona texture between pigeonite and fayalite suggests that fayalite crystallizes at lower temperature than pigeonite.

\subsection{Pipliya Kalan and Béréba eucrites}

It is established that most of the eucrites are monomict breccias and defined as pyroxeneplagioclase achondrites. Minor orthopyroxene ( 10\%) may also be present (Duke and Silver 1967; Takeda 1997; Hutchison 2004). Broadly, on the basis of petrography, eucrites may be recognized as cumulate and basaltic noncumulate types (Stolper 1977; Takeda 1997). It is suggested that cumulate and basaltic noncumulate variety of eucrites differ texturally and in terms of mineral chemistry; pyroxenes in cumulate variety show higher-Mg contents than pyroxenes in basaltic noncumulate variety (Consolmagno and Drake 1977; Stolper 1977). Other primary difference is the absence of ophitic texture in cumulate variety. The portion of Béréba eucrite studied during the present study shows brecciated cumulate texture consisting mainly of high-Mg pyroxenes, i.e., clinoenstatite; rarely any plagioclase grain is noticed. Absence or rare presence of plagioclase is really unexpected because most of the known eucrites contain considerable amount of plagioclase. This is most likely that the studied portion of Béréba eucrite is a fragment of pyroxene cumulate portion.

Pipliya Kalan eucrite is studied by a number of authors for its petrological characteristics and thermal history (Shukla et al. 1997; Bhandari et al. 1998; Buchanan et al. 2000; Hutchison 2004). Most of them have noted metamorphic effect on this eucrite; probably because of this reason, pyroxenes of the studied sample have not given good total during EPMA analyses. Shukla et al. (1997) have classified Pipliya Kalan eucrite as brecciated
Ca-rich achondrites and noticed several different lithologies and clasts, classified as noncumulate group of eucrites. Lithic clasts in a brecciated matrix in the Pipliya Kalan eucrite are also noticed by Buchanan et al. (2000). These authors have classified this eucrite as a genomict breccia which probably crystallized from a slow-cooling basaltic melt. Chemical composition supports its relation to the main group eucrites, however fractional crystallization also played important role in its genesis. Hornfelsic texture and minerals observed in Pipliya Kalan eucrite indicate evidence of an extensive thermal metamorphism (Buchanan et al. 2000). Sears et al. (1997) have described metamorphic history of eucrites in detail. It is suggested that thermal metamorphism observed in the Pipliya Kalan eucrite occurred $\sim 4.56 \mathrm{Ga}$ (Srinivasan et al. 1999). The thermal history of the Piplia Kalan eucrite is also discussed by Bhandari et al. (1998). They suggested that although $\mathrm{Pu}-\mathrm{Xe}$ age indicates its formation $\sim 4.56 \mathrm{Ga}$, their younger $\mathrm{K}-\mathrm{Ar}$ and $\mathrm{U}-$ He ages indicate impact event leading to thermal metamorphism later in its history.

The piece of Pipliya Kalan eucrite sample examined during the present study shows mineral compositions and texture similar to the noncumulate basaltic rocks. Although pyroxene grains of this sample show lots of alterations, probably due to thermal metamotphism, however magmatic ophitic texture is still preserved nicely. Hypidiomorphic texture is also noticed at places. Pyroxene grains are altered and have not given a good total during the EPMA, but obtained data suggest presence of clinoenstatite and pigeonite. Plagioclase feldspars are fresh and range in compositions from bytownite to anorthite. It is important to mention that there is no brecciated texture observed during the present study, as observed by earlier researchers (Shukla et al. 1997; Buchanan et al. 2000). This suggests that probably studied piece of sample is from a meteorite that did not experience any early shock event. However, it has suffered a late thermal metamorphic event. Presence of clinoenstatite and pigeonite suggest its crystallization from a high-temperature basaltic melt (Stolper 1977) crystallized at low pressure (Huebner 1980).

On the other hand, observed petrographic features and mineral chemistry of the studied Béréba eucrite probably indicate its cumulate nature, which is well-supported by presence of high-Mg clinopyroxenes, i.e., clinoenstatite (cf. Consolmagno and Drake 1977; Stolper 1977; Mayne et al. 2009). Stolper (1977) has discussed possible petrogenetic processes for the basaltic noncumulate eucrites and suggested that they are probably derived from a large-degree melts of a chondritic planetary body leaving a mineral composition similar to a gabbroic rock (olivine \pm clinopyroxene \pm 
pigeonite + plagioclase) in residue. However, this is not supported by $\mathrm{Sm} / \mathrm{Nd}$ and $\mathrm{Lu} / \mathrm{Hf}$ ratios as the strong fractionation of these ratios in cumulates reflects the presence of residual ilmenite during melting (Blichert-Toft et al. 2002). These authors suggested that cumulate eucrites were formed by small-degree melts of ilmenite-bearing gabbros and probably cumulate eucrites are about $100 \mathrm{Ma}$ younger than basaltic eucrites, the age that is similar to the Solar System (Lugmair and Shukolyukov 1998). Chemically cumulate eucrites show low-Ti and low Fe/Mg ratios (Stolper 1977; Barrat et al. 2000). Studied Béréba eucrite also shows similar chemical nature (see table 5). Presence of clinoenstatite in Béréba eucrite indicates its derivation from a high-temperature $\left(>1100^{\circ} \mathrm{C}\right)$ basaltic melt (cf. Stolper 1977). Stolper (1977) suggested that due to crystal settling and slow cooling may form cumulate eucrites without any metamorphic effect. Observed brecciation in the sample might be because of impacts (cf. Takeda 1997).

Blichert-Toft et al. (2002) have suggested that probably both varities of eucrites have different origin. On the basis of $\mathrm{Sm}-\mathrm{Nd}$ isotope systematic they observed that both varities have different isochron ages; $4470 \pm 22 \mathrm{Ma}$ for the cumulate eucrites, whereas basaltic eucrites show $4604 \pm$ 39 Ma. Blichert-Toft et al. (2002) further suggested that basaltic eucrites probably formed as large-degree melts of a chondritic source, whereas cumulates were derived by small-degree melts of ilmenite-bearing gabbros. Younger age of cumulate eucrite is also noticed from $\mathrm{Ar}-\mathrm{Ar}$ age data (4.25 Ga; Bogard and Garrison 2003) and $\mathrm{Pb}-$ $\mathrm{Pb}$ age data (4.484-4.399 Ga; Tera et al. 1997). Bogard (1995) suggested that younger ages might represent period of impact modification. Recently, zircon grains from basaltic eucrites, which also includes Béréba eucrite, have been dated by Zhou et al. (2011a, b). They suggested peak basaltic volcanism at $\sim 4545 \mathrm{Ma}$ on Vesta. The weighted mean of ${ }^{207} \mathrm{~Pb} /{ }^{206} \mathrm{~Pb}$ age of $4551 \pm 20 \mathrm{Ma}$ is obtained for Béréba eucrite by them. The age of peak basaltic volcanism on Vesta is further refined to $\sim 4550 \mathrm{Ma}$ by Zhou et al. (2011b) on the basis of U-Pb isotope systematics of zircon and apatite of Cachari and Béréba eucrites. These ages clearly indicate that cumulate eucrites are comparatively younger in age than basaltic eucrite and have different origin.

\subsection{Johnstown diogenite}

Diogenites are either monomic breccias or unbrecciated type dominantly composed of Ca-poor pyroxenes, particularly orthopyroxenes (Takeda and Mori 1985; Bowman et al. 1997; Takeda 1997). Plagioclase feldspar may present in small amounts $(\sim 10 \%)$. The studied Johnstown diogenite show hypidiomorphic to ophitic textures and at places brecciated nature is also observed. It consists of ferrosilites and anorthitic plagioclase feldspars. Both of these minerals are supposed to have been crystallized at higher temperatures from a basaltic melt. In general, diogenites are supposed to be a cumulate rock with their compositions similar to the orthopyroxenites and harzburgites and a number of models are proposed for their origin (Shearer et al. 2010 and references therein), however, studied Johnstown diogenite sample does not show any cumulate texture. Birck and Allègre (1981) have studied a number of diaogenite samples including Johnstown for their $\mathrm{Sr}$ isotope compositions and stated that these samples give scattered data in the ${ }^{87} \mathrm{Rb} /{ }^{86} \mathrm{Sr},{ }^{87} \mathrm{Sr} /{ }^{86} \mathrm{Sr}$ diagram and they plot close to the eucrite isochron. This suggests a genetic link between eucrites and diogenites and, by inference; diogenites may also have similar origin as eucrites. On the basis of the major and trace element abundances and the $\mathrm{FeO} / \mathrm{MgO}$ ratios of the diogenites (both Mg-rich and Mg-poor varieties), Barrat et al. (2008) observed that chemical characteristics of diaogenites overlap with noncumulate eucrites. They suggested that diogenites were derived from liquids produced by the re-melting of cumulates formed from the magma ocean. This inference is very similar to what is observed from the present study. The chemical diversity observed in diogenites strongly suggest their origin from different melts; single magma cannot explain this diversity (Barrat et al. 2008). Barrat et al. (2009) discovered K-rich impact glasses in howardites which states that the rocks that crop out on Vesta are certainly not restricted to eucrites and ultramafic cumulates. Considering these petrographic and mineral chemistry characteristics, it is suggested that Johnstown diogenite is derived from slow cooling of a Capoor basaltic melt derived from cumulates formed from the magma ocean, similar to origin of the noncumulate eucrites.

\section{Conclusions}

On the basis of petrography and mineral chemistry presented above for the five samples HED clan achondrites, which include Bholghati howardite, Lohabat howardite, Pipliya Kalan eucrite, Béréba eucrite and Johnstown diogenite, following conclusions may be drawn:

- Two studied samples of howardite (Bholghati and Lohawat howardites) are polymict breccias. 
They contain lithic clast (pieces of eucrites and diaogenites), mineral clasts (mostly different varieties of pyroxenes and minor ilmenite) and pure iron metallic phase. Eucrite clasts are noncumulate basaltic in nature, whereas diogenite clasts are mostly composed of orthopyroxene with minor clinopyroxene and anorthite. Orthopyroxene, clinopyroxene, minor olivine (fayalite) and iron oxides (chromite, ilmenite and even pure iron metal) are present as mineral clasts. Pyroxene compositions observed in both the studied howardites are very similar; both contain orthopyroxene, pigeonite and augite and have very similar pyroxene compositions observed in other known diogenites. Some remarkable attributes observed in Lohawat howardite suggest that orthoenstatite crystallizes first at a high-temperature followed by ferrosilite, pigeonite olivine and augite from a basaltic melt.

- Pipliya Kalan eucrite shows mineral compositions and texture similar to the noncumulate basaltic rocks. Although pyroxene grains of this sample are altered, they preserve ophitic and hypidiomorphic textures. Clinoenstatite and pigeonite are main pyroxenes present in this eucrite. There is no brecciated texture observed in this sample which ultimately suggests that probably it is not suffered by any early shock event. However, they subsequently suffered a thermal metamorphic event. Presence of clinoenstatite and pigeonite suggest their crystallization from a high-temperature basaltic melt crystallized at low pressure. On the other hand, petrographic features and mineral chemistry observed for the Béréba eucrite probably indicate its cumulate nature and its formation by smalldegree melts of ilmenite-bearing gabbros. Presence of clinoenstatite (a high-Mg pyroxene) indicates its derivation from a high-temperature $\left(>1100^{\circ} \mathrm{C}\right)$ basaltic melt. Crystal settling and slow cooling rate are important factors to form cumulate nature of this eucrite without any metamorphic effect. Observed brecciated nature might be because of impacts.

- Johnstown diogenite shows hypidiomorphic to ophitic textures and at places even brecciated nature is also observed. Most pyroxene and plagioclase feldspar grains are altered. Analysed minerals suggest presence of ferrosilite and anorthite. In contrast to other known diaogenites, this sample does not show any cumulate texture. Observed petrographic and mineral chemistry characteristics suggest that Johnstown diogenite is derived from slow cooling of a Ca-poor basaltic melt derived from cumulates formed from the magma ocean, similar to origin of the noncumulate eucrites.

\section{Acknowledgements}

The author is grateful to Prof. J N Goswami (Director, PRL and Co-ordinator, PLANEX Programme) for introducing him this interesting and exciting topic for research. Author is also thankful to Prof. N Bhandari for providing three achodritic samples for this study. Financial assistance provided by PLANEX Programme, PRL, Ahmedabad is thankfully acknowledged. Author would like to thank Prof. S V S Murty for his continuous encouragement and help during this work. He is also grateful to Dr N V Chalapathi Rao for his help in generating EPMA data of the studied samples at IBM, Nagpur and his constructive suggestions during preparation of this paper. Author is grateful to two anonymous reviewers for their useful and constructive comments which certainly helped to improve this paper considerably.

\section{References}

Barrat J A 2004 Determination of the parental magmas of HED cumulates: The effects of interstitial melts; Meteoritics Planet. Sci. 39 1767-1779.

Barrat J A, Blichert-Toft J, Gillet P and Keller F 2000 The differentiation of eucrites: The role of in situ crystallization; Meteoritics Planet. Sci. 35 1087-1100.

Barrat J A, Jambon A, Bohn M, Blichert-Toft J, Sautter V, Göpel C, Gillet Ph, Boudouma O and Keller F 2003 Petrology and geochemistry of the unbrecciated achondrite North West Africa 1240 (NWA 1240): An HED parent body impact melt; Geochim. Cosmochim. Acta 67 3959-3970.

Barrat J A, Yamaguchi A, Benoit M, Cotton J and Bohn M 2008 Geochemistry of diogenites: Still more diversity in their parental melts; Meteoritics Planet. Sci. 43 1759-1775.

Barrat J A, Bohn M, Gillet Ph and Yamaguchi A 2009 Evidence for K-rich terranes on Vesta from impact spherules; Meteoritics Planet Sci. 44 359-374.

Barrat J A, Yamaguchi A, Zanda B, Bollinger C and Bohn M 2010 Relative chronology of crust formation on asteroid Vesta: Insights from the geochemistry of diogenites; Geochim. Cosmochim. Acta 74 6218-6231.

Bhandari N, Murty S V S, Suthar K M, Shukla A D, Ballabh G M, Sisodia M S and Vaya V K 1998 The orbit and exposure history of the Piplia Kalan eucrite; Meteoritics Planet. Sci. 33 455-461.

Biggar G M 1985 Calcium-poor pyroxenes: Phase relations in system $\mathrm{CaO}-\mathrm{MgO}-\mathrm{A}_{2} \mathrm{O}_{3}-\mathrm{SiO}_{2} ;$ Mineral Mag. 49 49-58.

Birck J L and Allègre C J $1981{ }^{87} \mathrm{Rb} / /{ }^{87} \mathrm{Sr}$ study of diogenites; Earth Planet. Sci. Lett. 55 116-122.

Blichert-Toft J, Boyet M, Télouk P and Albarède F 2002 ${ }^{147} \mathrm{Sm}^{-143} \mathrm{Nd}$ and ${ }^{176} \mathrm{Lu}^{-176} \mathrm{Hf}$ in eucrites and the differentiation of the HED parent body; Earth Planet. Sci. Lett. 204 167-181.

Bogard D D 1995 Impact ages of meteorites: A synthesis; Meteoritics 30 244-268.

Bogard D D and Garrison D H $2003{ }^{39} \mathrm{Ar}-{ }^{40} \mathrm{Ar}$ ages of eucrites and thermal history of asteroid 4 Vesta; Meteoritics Planet. Sci. 38 669-710. 
Bowman L E, Spilde M N and Papike J J 1997 Automated energy dispersive spectrometer modal analysis applied to the diogenites; Meteoritics Planet. Sci. 32 869-875.

Buchanan P C, Mittlefehldt D W, Hutchison R, Koeberl C, Lindstrom D J and Pandit M K 2000 Petrology of the Indian eucrite Piplia Kalan; Meteoritics Planet. Sci. 35 609-615.

Clayton R N and Mayeda T K 1996 Oxygen isotope studies of achondrites; Geochim. Cosmochim. Acta $\mathbf{6 0}$ 1999-2018.

Consolmagno G Y and Drake M J 1977 Composition and evolution of the eucrite parent body: Evidence from rare earth elements; Geochim. Cosmochim. Acta 41 1271-1282.

Delaney J S, Nehru C E and Prinz M 1980 Olivine clasts from mesosiderites and howardites: Clues to the nature of achondrites parental bodies; Proceedings of the Lunar Planetary Science 11th, pp. 1073-1087.

Drake M J 2001 The eucrite/Vesta story; Meteoritics Planet. Sci. 36 501-513.

Duke M B and Silver L T 1967 Petrology of eucrites, howardites and mesosiderites; Geochim. Cosmochim. Acta 31 1637-1665.

Huebner J S 1980 Pyroxene phase equilibria at low pressure; In: Reviews in Mineralogy, Pyroxene (ed.) Prewitt C T; Mineral Soc. Am. 7 213-288.

Hutchison R 2004 Meteorites: A petrologic, chemical and isotope synthesis. Cambridge Univ. Press, Cambridge, 506 p.

Labotka T C and Papike J J 1980 Howardites: Samples of the regolith of the eucrite parent-body: Petrology of Frankfort, Pavlovka, Yurtuk, Malvern, and ALHA 77302; Proceedings of Lunar Planetary Science 11th, pp. 1103-1130.

Lugmair G W and Shukolyukov A 1998 Early solar system timescales according to $53 \mathrm{Mn}-53 \mathrm{Cr}$ systematics; Geochim. Cosmochim. Acta 62 2863-2886.

Mayne R G, McSween Jr H Y, McCoy T J and Gale A 2009 Petrology of the unbrecciated eucrites; Geochim. Cosmochim. Acta $\mathbf{7 3}$ 794-819.

McSween Jr H Y 1999 Meteorites and their parent planets; Cambridge Univ. Press, Cambridge, 310p.

McSween Jr H Y, Mittlefehldt D W, Beck A W, Mayne R G and McCoy T J 2011 HED meteorites and their relationship to the geology of Vesta; Space Sci. Rev. 163 371-459.

Mittlefehldt D W 2005 Achondrites; In: Meteorites, Comets and Planets, Treatise in Geochemistry (ed.) Davis A M (Elsevier: Amsterdam), pp. 291-324.

Mittlefehldt D W, McCoy T J, Goodrich C A and Kracher A 1998 Non-chondritic meteorites from asteroidal bodies; In: Planetary Materials (eds) Papike J J et al., Mineral. Soc. Am., Washington, pp. 1-195.
Morimoto N, Fabries J, Ferguson A K, Ginzburg I V, Ross M, Seifert F A, Zussman J, Aoki K and Gottardi G 1988 Nomenclature of pyroxenes; Am. Mineral 73 1123-1133.

Norton O R 2002 Encyclopedia of meteorites; Cambridge Univ. Press, Cambridge, 354p.

Sears D W G, Symes S J K, Batchelor J D, Akridge D G and Benoit P H 1997 The metamorphic history of eucrites and eucrite-related meteorites and case for late metamorphism; Meteoritics Planet. Sci. 32 917-927.

Shukla A D, Shukla P N, Suthari K M, Bhandari N, Vaya V K, Sisodia M S, Sinha Roy S, Rao K N and Rajawat R S 1997 Piplia Kalan eucrite: Fall, petrography and chemical characteristics; Meteoritics Planet. Sci. 32 611-415.

Shearer C K, Burger P and Papike J J 2010 Petrogenetic relationships between diogenites and olivine diogenites: Implications for magmatism on the HED parent body; Geochim. Cosmochim. Acta 74 4865-4880.

Sisodia M S, Shukla A D, Suthar K M, Mahajan R R, Murty S V S, Shukla P N, Bhandari N and Natarajan R 2001 The Lohawat howardite: Mineralogy, chemistry and cosmogenic effects; Meteoritics Planet. Sci. 36 1457-1466.

Srinivasan G, Goswami J N and Bhandari N $1999{ }^{26} \mathrm{Al}$ in eucrite Piplia Kalan: Plausible heat source and formation chronology; Science 284 1348-1350.

Stolper E 1977 Experimental petrology of eucritic meteorites; Geochim. Cosmochim. Acta 41 587-611.

Takeda H 1997 Mineralogical records of early planetary processes on the howardite, eucrite, diogenite parent body with reference to Vesta; Meteoritics Planet. Sci. 32 841-853.

Takeda H and Mori H 1985 The diogenite-eucrite links and the crystallization history of a crust of their parent body; In: Proceedings of Lunar Planetary Science Conference 15th, Part 2, J. Geophys. Res. 90 C636-C648.

Tera F, Carlson R W and Boctor N Z 1997 Radiometric ages of basaltic achondrites and their relation to the early history of the solar system; Geochim. Cosmochim. Acta 61 1713-1731.

Vaya K, Mehta S, Bafna C, Sisodia S and Shrivastava K L 1996 The Pipliya meteor shower: A preliminary study; Curr. Sci. 71 253-355.

Zhou Q, Yin Q Z, Wu F Y, Li L, Li X Z, Liu Y and Tang G Q 2011a U-Pb and $\mathrm{Pb}-\mathrm{Pb}$ dating of small zircons in eucrites; In: Formation of the First Solids in the Solar System, p. 9107.

Zhou Q, Yin Q-Z, Bottke B, Claeys P, Li X-H, Wu F-Y, Liu Y and Tang G-Q 2011b Early basaltic volcanism and late heavy bombardment on Vesta: U-Pb ages of small zircons and phosphates in eucrites; 42nd Lunar Planetary Science Conference, The Woodlands, Texas, LPI Contribution No. 1608, p. 2575. 